\title{
Human herpes viruses in burn patients: A systematic review
}

Paul Wurzer, MD ${ }^{\mathrm{a}, \mathrm{b}}$; Ashley Guillory, PhD ${ }^{\mathrm{a}}$; Daryousch Parvizi, MD ${ }^{\mathrm{b}}$; Robert P. Clayton, BS ${ }^{\mathrm{a}, \mathrm{c}}$;

Ludwik K. Branski, MD MMS ${ }^{a, b}$; Lars-P. Kamolz, MD PhD ${ }^{\text {b }}$; Celeste C. Finnerty, PhD ${ }^{\mathrm{a}, \mathrm{c}}$; David N. Herndon, MD FACS ${ }^{\text {; }}$ Jong O. Lee, MD FACS ${ }^{a}$

${ }^{a}$ Department of Surgery, University of Texas Medical Branch and Shriners Hospitals for Children, Galveston, Texas

${ }^{b}$ Division of Plastic, Aesthetic and Reconstructive Surgery, Department of Surgery, Medical University of Graz, Graz, Austria

'Sealy Center for Molecular Medicine and the Institute for Translational Sciences, University of Texas Medical Branch, Galveston, Texas

Running Title: Human herpes viruses in burns

Corresponding Author: Paul Wurzer, MD; Shriners Hospitals for Children, 815 Market Street, Galveston, Texas 77550, USA; Tel: +1 409770 6974, fax: +1 4097706919

E-mail address: wurzer paul@gmx.at (P. Wurzer).

\section{Acknowledgements}

The authors thank Dr. Kasie Cole for editing and proofreading of the manuscript. This study was supported by the National Institutes of Health (P50-GM060338, R01-GM056687, R01HD049471, R01-112936-01 and T32-GM008256), the Shriners Hospitals for Children (71008, $80100,84080,84291)$ and the United States Department of Defense (W81XWH-14-2-0162).

\section{Authors' contributions}

All authors made substantial contributions to the development or design of the work (AG, JOL, $\mathrm{PW}, \mathrm{RPC}$ ) or to the acquisition, analysis, or interpretation of data for the work (AG, DP, PW, RPC) and the drafting of the work or revising the intellectual content (all authors).

Keywords: Human herpes virus, herpes simplex virus, varicella-zoster virus, chickenpox, cytomegalovirus, burns 


\section{Abstract}

Objective: The contribution of human herpes viruses, including herpes simplex virus (HSV), cytomegalovirus (CMV), and varicella zoster virus (VZV) to morbidity and mortality after burns remains controversial. This systematic review was undertaken to assess evidence of herpes virus-related morbidity and mortality in burns.

Materials and Methods: PubMed, Ovid, and Web of Science were searched to identify studies of HSV, CMV, or VZV infections in burn patients. Exclusion criteria included: A level of evidence (LoE) of IV or V; nonhuman in vivo studies; and non-English articles. There was no limitation by publication date.

Results: Fifty articles were subjected to full-text analysis. Of these, 18 had LoE between I-III and were included in the final review (2 LoE I, 16 LoE II-III). Eight had a prospective study design, 9 had a retrospective study design, and 1 included both.

Conclusions: No direct evidence linked CMV and HSV infection with increased morbidity and mortality in burns. Following burn injury, CMV reactivation was more common than a primary CMV infection. Active HSV infection impaired wound healing but was not directly correlated to mortality. Infections with VZV are rare after burns but when they occur, VZV infections were associated with severe complications including mortality. The therapeutic effect of antiviral agents administered after burns warrants investigation via prospective randomized controlled trials. 


\section{Introduction}

Bacterial and viral infections such as cellulitis, pneumonia, wound infections, and septicemia are among the most common complications following burn injury [1]. An increased inflammatory response and overall immunosuppression occur following massive thermal injuries [2-4]. Burn-related phenotypic changes in T-cells contribute to post-burn immunosuppression [5]. Also, defective natural killer cell activity against virus-infected cells weakens the immune response of these severely injured patients [6]. As a result of these burn-induced changes, severely burned patients are more prone to infections and septicemia [7]. Studies have shown that sepsis and infections enhance the hypermetabolic response [2], which negatively affects the long-term outcomes of severely burned patients for up to 2 years post burn [4]. Along with bacterial infections, viral infections have been associated with increased morbidity and mortality in the severely burned [7-11]. Viral infections in burns are thought to promote bacterial and other infections [12]. Early treatment of sepsis and prevention of infections are a key component to reducing morbidity and improving the long-term outcome of burn victims.

The human herpes virus (HHV) family includes herpes simplex virus type 1 (HSV-1), herpes simplex virus type 2 (HSV-2), varicella zoster virus (VZV), cytomegalovirus (CMV), Epstein-Barr viruses (EBV), and human herpes virus 6 to 8 [13]. In immunosuppressed burn patients, primary infections or a reactivation of viral infections with HSV-1, HSV-2, or CMV are common complications during hospitalization. Primary infection or vaccination results in a seroprevalence of immunoglobulin $\mathrm{G}(\mathrm{lg} G)$ antibodies against the virus. Of note, the overall HSV-2 seroprevalence rate in the U.S. is $21.9 \%$ according to an analysis of more than 13,000 serum samples [14]. In Australia, a study showed a seroprevalence of $75 \%$ for HSV-1 and $12 \%$ for HSV-2 in the adult population [15]. Seroprevalence for CMV was found to be $50.4 \%$ [16]. In contrast to natural immunity against other $\mathrm{HHV}$, that against VZV is being replaced by vaccineinduced immunity in many countries to protect against herpes zoster infections in older individuals who did not receive immunity during chickenpox infection [17]. However, about 95\% 
of adults have acquired immunity against VZV infections owing to chickenpox exposure in childhood $[13,18]$.

In order for HSV to be transmitted, there must be contact between a virus-shedding person and a susceptible host. The primary infection can cause symptoms ranging from fever, characteristic vesicles with erythematous base, on to viremia and visceral dissemination [13]. Severe HSV infections promotes bacterial infections in burns and prolongs the postburn recovery process [12], and thus, HSV infections can be associated with a higher mortality $[9,19]$.

In a review of CMV in burns, Rennekampff and Hamprecht concluded that allografts and blood transfusions can be sources of infections [20]. They showed that there is no direct evidence that CMV infections directly increase morbidity and mortality of severely burned patients [21,22]. Furthermore, antiviral therapy for CMV infections in burns is still controversial $[23,24]$.

Infections with VZV in burns are rare, although burn wound colonization with VZV has been well described [25-27]. VZV immunity, imparted by childhood chickenpox infections or VZV vaccination, seems to prevent burn-induced VZV infections [28].

HSV, CMV, and VZV infections are believed to play a pivotal role in morbidity and mortality in burns. Thus far, there is no existing systematic review (citing Level III evidence or higher) describing the contributions of these viruses to poor burn outcomes or concurrent infections. The aim of this review is to delineate the clinical differences between these human herpes virus subtypes, to outline established therapy approaches, and to evaluate evidence for virus-related morbidity and mortality in burns. 


\section{Methods}

The review protocol was registered in the clinicaltrials.gov database (\#SHC-G-SR-HHV). This systematic review was created according to the PRISMA (Preferred Reporting Items for Systematic reviews and Meta-Analyses) guidelines and checklist [29].

\subsection{Search strategy and sources}

We reviewed the medical literature in order to identify all studies of HSV, CMV, and VZV infections in burns. A systematic review of the Medline database was conducted using both, the PubMed (accessed 04/09/2015) and Ovid (accessed 04/09/2015) interfaces. The Web of Science (accessed 04/16/2015) interface was also used for a systematic literature search. We limited the search to only articles written in the English language. There was no restriction on the date of publication for any of these searches.

On the PubMed interface, we used the following search terms: ("HSV"[All Fields] OR "herpes"[All Fields] OR "CMV"[All Fields] OR "cytomegalovirus"[All Fields] OR "VZV"[All Fields]

OR "varicella-zoster"[All Fields]) AND ("burns"[MeSH Terms] OR "burns"[All Fields] OR "burn"[All Fields] OR "thermal trauma"[All Fields]). For Ovid we used the following: exp Burns/ AND (exp Herpes Zoster/ or exp Encephalitis, Herpes Simplex/ or exp Herpes Simplex/ or exp Herpes Simples Virus Vaccines/), exp Burns/ AND (exp Cytomegalovirus/ or exp Cytomegalovirus Infections/), exp Burns/ AND (exp Chickenpox/ or Herpesvirus 3. Human/ or exp Herpes Zoster/). For Web of Science we used the following: (TS=(HSV OR herpes OR CMV OR cytomegalovirus OR VZV OR varicella-zoster) AND TS=(burn OR burns OR thermal trauma)) AND LANGUAGE: (English) AND DOCUMENT TYPES: (Article); Timespan: All years; Indexes: SCI-EXPANDED, SSCI, A\&HCI, CPCI-S. 


\subsection{Data extraction and eligibility criteria}

Results from each search interface were automatically imported into an Excel 2010 spreadsheet (Microsoft, Richmond, VA, USA). Automatic and manual screenings for duplicates were completed. Through screening of abstracts, we were able to identify all articles containing human herpes virus infections in the context of human burn/burns/thermal injuries for further qualitative analysis. All articles that had been defined as non-in vivo human studies were excluded from the analysis.

Full-text analysis of the remaining articles allowed a qualitative analysis of the studies. The Level of Evidence (LoE) of each study was obtained by grading according to the scale developed by the American Society of Plastic Surgeons for prognostic and therapeutic studies [30]. The literature search and rating of the articles was obtained by two independent raters (PW, RPC), and discrepancies were resolved through a discussion. Both ratings stratified articles according to LoE.

All articles with a LoE IV or V (case reports/studies, reviews including case reports/studies, expert opinions, personal observations, letters to the editor, comments) were excluded from the final review process to ensure a LoE of III for the performed systematic analysis. Three reviewers (AG, DP, PW) screened all articles that met the inclusion criteria for type of virus infection, number of patients, mean age, mean total body surface area (TBSA) burned, morbidity and mortality, seroprevalences, and origin of virus isolation. A brief summary of the aim, results, and main conclusion of each study were created. A flowchart based on the PRISMA guidelines [29] depicting the review process was created in PowerPoint 2010 (Microsoft, Richmond, VA, USA). 


\section{Results}

Seven hundred ninety-nine articles were identified from the three search interfaces using the previously mentioned search terms (Figure 1). After removal of duplicates, 595 abstracts were screened for CMV, HSV, and VZV in the context of burns. Unrelated articles, non-English articles, and non-in vivo studies were excluded. The remaining 50 articles were then graded according to their LoE. Case reports $(n=17)$, case series $(n=5)$, letters $(n=4)$, and a survey article were excluded. Five review articles (3 LoE IV and 2 LoE V) were also excluded. Eighteen LoE I-III articles were included in the systematic review. Two studies graded as LoE I were prospective randomized double-blind trials. Eight ( $n=513$, number of patients) of the studies were prospective analyses; nine $(n=9,690)$ had a retrospective study design. Linnemann and MacMillan [27] investigated adenovirus, CMV, EBV, HSV, and VZV retrospectively $(n=40)$ and adenovirus, CMV, and HSV prospectively $(n=24)$. Overall, CMV was discussed in 14 articles, HSV in eight, and VZV in three. Matthews et al. [26] also reported vaccinia in their studied cohort. Eleven articles did not discuss antiviral therapy; 3 mentioned antiviral treatment regimens but they were not used, and 2 discussed immunoglobulin $\mathrm{G}(\mathrm{Ig} G)$ therapy for CMV infections. In 2 studies, Acyclovir was used as an antiviral therapy for HSV infections [12,31]. Sheridan et al. [28] discussed acyclovir and IgG antiviral therapy managements for VZV infections. Further details of and a summary of each study are provided in Tables 1 and 2. 


\section{Discussion}

\subsection{Cytomegalovirus}

In addition to CMV-positive blood transfusions, cadaver skin was described as a source of CMV infections in burn patients in a prospectively performed study by Kealey and colleagues [32]. These findings confirm previously published results in animal studies [33,34]. The overall seroprevalence of CMV in burn patients ranges from 37\% reported by Kealey et al. [21] to 73\% reported by Seeman and Koenigova [35]. This is consistent with the CMV seroprevalence of $50 \%$ in the healthy U.S. population [16]. Since $50 \%$ of all people are latent CMV hosts, the recommendation of avoiding the transfer of CMV-positive blood transfusions and allogenic skin to burn patients is warranted but may not be possible [36]. Interestingly, Bordes et al. [37] suggested that CMV infections are due to reactivation of latent CMV rather than a primary CMV infection. Gong et al. [38] also showed a CMV reactivation in 108 out of 160 burn patients who were CMV-IgG-seropositive on admission.

While Seeman and Koenigova [35] found that elevated CMV serum titers were associated with pneumonia in three cases, Bale et al. [22] did not find clinically relevant CMV infections in 120 observed patients. In a prospective analysis of 23 burn patients who were CMV-seronegative at admission, three seroconverted patients demonstrated symptoms of persistent fever, elevated liver enzymes, and diarrhea [32]. A higher number of CMV copies/ml blood was associated with more major infections, more ventilator days, and a longer hospitalization [37].

Two studies suggest that CMV may contribute to viral infection-related mortality in burn patients [35,39]. However, Kagan et al. [40] did not observe a difference in mortality between CMV-infected and non-infected burn patients. Three additional studies failed to find a correlation between CMV infections and greater mortality [21,23,24]. Linnemann and MacMillan [27] pointed out that, in case of unexplained fever and hepatitis in burned children, CMV should be considered as a differential diagnosis; however, no correlation between CMV and mortality was 
found. D'Avignion et al. [7] concluded that the effects of viral infections on mortality need to be further investigated.

In the study by Munster and colleagues [23], prophylactic intravenous immunoglobulin therapy was used to prevent CMV infection in burn patients. The authors found no difference in treated and untreated patients in mortality or sepsis. They also showed that the CMV IgG titer of the treated patients returned to normal 7 days after the last immunoglobulin therapy. In a later prospective study, Moran et al. [24] prophylactically treated CMV-seronegative patients with intravenous immunoglobulin at 7 day intervals. There was not a significant difference between treated and control groups. Kealey et al. discussed the use of ganciclovir as a prophylactic therapy against CMV infections in burns, a therapy that has not been investigated to date [32]. The overall conclusion of these studies was that a prophylactic intravenous immunoglobulin therapy for burn patients is not advisable as it does not improve morbidity and mortality in CMVinfected burn patients.

\subsection{Herpes simplex virus}

HSV-1 and HSV-2 share the most common clinical symptoms; however, their genomic homology is about 50\% [13]. Whereas HSV-1 infections are located orally, HSV-2 infections usually occur on the skin around the genitals. In burns, primary infection with HSV or reactivation due to immunodeficiency is possible. In most cases, a prior HSV-1 infection attenuates the severity of subsequent HSV-2 infections. In the Australian population, a general HSV-1 seroprevalence of $75 \%$ was seen; thus, a reactivation of the virus should be considered in the immunosuppressed burn patient [15]. A retrospective analysis by Bourdarias et al. [41] revealed clinically significant HSV-1 infections in 11 of 280 analyzed patients who had a mean age of 39 years at the time of the burn; however, IgG serum titers for HSV were not obtained at admission. A histological analysis of lung tissue from burn patients by Byers et al. showed a $50 \%$ prevalence of HSV; however, the serum titer level for HSV was not described. In a study of 
30 burn patients, clinically active HSV infections were described in 5 cases; another 2 patients suffered from a combination of HSV and CMV infection [26]. In another study, a serum prevalence of $8 \%$ for HSV was described in a population of 40 burned children [27].

In the study of Bourdarias et al. [41], patients with HSV-1 infections presented with fever and blisters in grafted areas, although there was no effect on length of hospitalization. Sen et al. [12] observed a greater length of mechanical ventilation and hospital stay in HSV-infected burn patients as well as a greater likelihood of acquiring bacterial infections. A correlation between length of hospitalization and occurrence of viral infections (CMV and/or HSV) was observed by Kagan et al. [40], suggesting that a more severe injury with a greater length of stay triggers viral infections in the burn population. Overall, these studies suggest that there may be a causal relationship between HSV infection during hospitalization and prolonged hospital stay. Interestingly, a correlation between mortality and HSV infections in burn patients was mentioned in an autopsy series of 54 burn patients, with pulmonary herpes being highly associated with acute respiratory distress syndrome and later death. No other study has shown an association between HSV infection in burns and increased mortality [12,26,27,31,41].

Bourdarias et al. [41] mentioned acyclovir as a treatment option; however, antiviral therapy was not used to treat any of the observed HSV-1 infections. In a retrospective chart review conducted by Fidler and colleagues [31], intravenous acyclovir therapy was described in 15 HSV-1 positive cases. In one case, worsened renal function was observed due to the intravenous antiviral treatment. However, no benefits of the acyclovir treatment could be seen. In most case reports and case series, authors suggest intravenous acyclovir therapy for clinically manifested HSV infections in burns [19,42-48]. Matthews et al. [26] discussed a prophylactic therapy with idoxuridine for acute HSV infections, however, this therapy was not used in their study. In a study by Nishimura et al. [49] in 1984, immunoglobulin therapy was given for manifested HSV infections. However, no established therapy for HSV infections in burns could be found in literature analyzed here. This agrees well with a systematic review 
performed by Jones et al. [50], which found a lack of evidence for the use of antiviral agents in the treatment of HSV in the nonburned population.

\subsection{Varicella zoster virus}

VZV is ubiquitously present, but infections in burns are rare [28]. Because of childhood chickenpox infections, $95 \%$ of adults have been immunized $[13,18]$. In the nonimmunized pediatric population, acute VZV infection in burns directly correlates with morbidity and mortality [28]. Severe scarring and neuralgia following VZV infection have been described in an adult burn patient [26]. The only study dealing with VZV in pediatric burns recommended prophylactic acyclovir therapy in nonimmunized pediatric burn patients [28]. However, the incidence of VZV in this study was described as $0.1 \%$. In summary, VZV infections in burns are rare, but in cases of an infection antiviral treatment is recommended.

\subsection{Combined infections}

A combination of several viruses causing a mixed viral infection can occur in the burn patient $[26,40]$. Combined HSV and CMV infection has been described by Matthews et al. [26] in 2 burn patients, but no effect on morbidity was seen. Kagan et al. [40] reported a combined HSV and CMV infection in thermally injured patients, but they concluded that, in burn patients, viral infections are masked by other factors such as bacterial infections. They suggested that patients with active viral infections are more prone to bacterial or other infections.

\subsection{Limitations}

Since only articles with a LoE I-III were included and single cases and case series were excluded, we were unable to perform a meta-analysis. Additionally, the variableness of the methods used to identify the viral infection hampered direct comparison of the reviewed studies. Finally, our study is limited to articles linked to Ovid, PubMed, and Web of Science. 


\section{Conclusions}

Reactivation of CMV seems to increase the risk for additional infections and ultimately results in a longer acute hospitalization. However, there is no evidence that CMV infections directly affect mortality. It is believed that reactivated infections are the main cause of clinical relevant HSV infections in burns owing to the immunosuppressed state of the patient. However, an active HSV infection impairs wound healing, and pulmonary HSV can be associated with acute respiratory distress syndrome; HSV infections have not been shown to increase mortality in these cases. In the case of an active VZV infection, morbidity and mortality are increased, but more studies are needed in order to confirm these results. Evidence supporting the effectiveness of standard antiviral therapy in infected burn patients is still lacking. 


\section{References}

[1] ABA-National Burn Repository 2013 Report Dataset Version 9.0 n.d. http://www.ameriburn.org/2013NBRAnnualReport.pdf.

[2] Herndon DN, Tompkins RG. Support of the metabolic response to burn injury. Lancet 2004;363:1895-902. doi:10.1016/S0140-6736(04)16360-5.

[3] Jeschke MG, Chinkes DL, Finnerty CC, Kulp G, Suman OE, Norbury WB, et al. Pathophysiologic response to severe burn injury. Ann Surg 2008;248:387-401. doi:10.1097/SLA.0b013e3181856241.

[4] Jeschke MG, Gauglitz GG, Kulp GA, Finnerty CC, Williams FN, Kraft R, et al. Long-term persistance of the pathophysiologic response to severe burn injury. PloS One 2011;6:e21245. doi:10.1371/journal.pone.0021245.

[5] Zedler S, Bone RC, Baue AE, von Donnersmarck GH, Faist E. T-cell reactivity and its predictive role in immunosuppression after burns. Crit Care Med 1999;27:66-72.

[6] Klimpel GR, Herndon DN, Fons M, Albrecht T, Asuncion MT, Chin R, et al. Defective NK cell activity following thermal injury. Clin Exp Immunol 1986;66:384-92.

[7] D'Avignon LC, Hogan BK, Murray CK, Loo FL, Hospenthal DR, Cancio LC, et al. Contribution of bacterial and viral infections to attributable mortality in patients with severe burns: an autopsy series. Burns J Int Soc Burn Inj 2010;36:773-9. doi:10.1016/j.burns.2009.11.007.

[8] Nash G, Asch MJ, Foley FD, Pruitt BA. Disseminated cytomegalic inclusion disease in a burned adult. JAMA 1970;214:587-8.

[9] Byers RJ, Hasleton PS, Quigley A, Dennett C, Klapper PE, Cleator GM, et al. Pulmonary herpes simplex in burns patients. Eur Respir J 1996;9:2313-7.

[10] Hamprecht K, Pfau M, Schaller H-E, Jahn G, Middeldorp JM, Rennekampff H-O. Human Cytomegalovirus Infection of a Severe-Burn Patient: Evidence for Productive Self-Limited Viral Replication in Blood and Lung. J Clin Microbiol 2005;43:2534-6. doi:10.1128/JCM.43.5.2534-2536.2005.

[11] Peppercorn A, Veit L, Sigel C, Weber DJ, Jones S, Cairns BA. Overwhelming disseminated herpes simplex virus type 2 infection in a patient with severe burn injury: case report and literature review. J Burn Care Res Off Publ Am Burn Assoc 2010;31:4928. doi:10.1097/BCR.0b013e3181db51cb.

[12] Sen S, Szoka N, Phan H, Palmieri T, Greenhalgh D. Herpes simplex activation prolongs recovery from severe burn injury and increases bacterial infection risk. J Burn Care Res Off Publ Am Burn Assoc 2012;33:393-7. doi:10.1097/BCR.0b013e3182331e28.

[13] Whitley RJ. Herpesviruses. In: Baron S, editor. Med. Microbiol. 4th ed., Galveston (TX): University of Texas Medical Branch at Galveston; 1996.

[14] Fleming DT, McQuillan GM, Johnson RE, Nahmias AJ, Aral SO, Lee FK, et al. Herpes simplex virus type 2 in the United States, 1976 to 1994. N Engl J Med 1997;337:1105-11. doi:10.1056/NEJM199710163371601.

[15] Cunningham AL, Taylor R, Taylor J, Marks C, Shaw J, Mindel A. Prevalence of infection with herpes simplex virus types 1 and 2 in Australia: a nationwide population based survey. Sex Transm Infect 2006;82:164-8. doi:10.1136/sti.2005.016899. 
[16] Bate SL, Dollard SC, Cannon MJ. Cytomegalovirus seroprevalence in the United States: the national health and nutrition examination surveys, 1988-2004. Clin Infect Dis Off Publ Infect Dis Soc Am 2010;50:1439-47. doi:10.1086/652438.

[17] Doerr HW. Progress in VZV vaccination? Some concerns. Med Microbiol Immunol (Berl) 2013;202:257-8. doi:10.1007/s00430-013-0298-x.

[18] Gnann JW. Varicella-zoster virus: atypical presentations and unusual complications. J Infect Dis 2002;186 Suppl 1:S91-8. doi:10.1086/342963.

[19] Brandt SJ, Tribble CG, Lakeman AD, Hayden FG. Herpes simplex burn wound infections: epidemiology of a case cluster and responses to acyclovir therapy. Surgery 1985;98:33843.

[20] Rennekampff $\mathrm{H}-\mathrm{O}$, Hamprecht K. Cytomegalovirus infection in burns: a review. J Med Microbiol 2006;55:483-7. doi:10.1099/jmm.0.46079-0.

[21] Kealey GP, Bale JF, Strauss RG, Massanari RM. Cytomegalovirus infection in burn patients. J Burn Care Rehabil 1987;8:543-5.

[22] Bale JF, Kealey GP, Massanari RM, Strauss RG. The epidemiology of cytomegalovirus infection among patients with burns. Infect Control Hosp Epidemiol 1990;11:17-22.

[23] Munster AM, Moran KT, Thupari J, Allo M, Winchurch RA. Prophylactic intravenous immunoglobulin replacement in high-risk burn patients. J Burn Care Rehabil 1987;8:37680.

[24] Moran KT, Thupari JN, O'Reilly TJ, Munster AM. Effect of immunoglobulin G therapy on serum antibody titers to cytomegalovirus in burn patients. Am J Surg 1988;155:294-7.

[25] Foley FD. Pathology of cutaneous burns. Surg Clin North Am 1970;50:1201-10.

[26] Matthews S, Levick P, Coombes E, Ely D, Pead P, Saeed A. Viral-Infections in a Group of Burned Patients. Burns 1979;6:55-60. doi:10.1016/0305-4179(79)90040-8.

[27] Linnemann CC, MacMillan BG. Viral infections in pediatric burn patients. Am J Dis Child $19601981 ; 135: 750-3$.

[28] Sheridan RL, Weber JM, Pasternak MM, Mulligan JM, Tompkins RG. A 15-year experience with varicella infections in a pediatric burn unit. Burns $\mathrm{J}$ Int Soc Burn Inj 1999;25:353-6.

[29] Moher D, Liberati A, Tetzlaff J, Altman DG, PRISMA Group. Preferred reporting items for systematic reviews and meta-analyses: the PRISMA statement. Ann Intern Med 2009;151:264-9, W64.

[30] American Society of Plastic Surgeons. Evidence-based Clinical Practice Guidelines 2015. http://www.plasticsurgery.org/Documents/medical-professionals/health-policy/evidencepractice/ASPS-Rating-Scale-March-2011.pdf (accessed April 17, 2015).

[31] Fidler PE, Mackool BT, Schoenfeld DA, Malloy M, Schulz JT, Sheridan RL, et al. Incidence, outcome, and long-term consequences of herpes simplex virus type 1 reactivation presenting as a facial rash in intubated adult burn patients treated with acyclovir. J Trauma 2002;53:86-9.

[32] Kealey GP, Aguiar J, Lewis RW, Rosenquist MD, Strauss RG, Bale JF. Cadaver skin allografts and transmission of human cytomegalovirus to burn patients. J Am Coll Surg 1996;182:201-5.

[33] Shelby J, Shanley J. Transfer of murine cytomegalovirus by syngeneic skin grafts. Transplantation 1987;44:318-20. 
[34] Shelby J, Saffle JR, Kern ER. Transmission of cytomegalovirus infection in mice by skin graft. J Trauma 1988;28:203-6.

[35] Seeman J, Konigová R. Cytomegalovirus infection in severely burned patients. Acta Chir Plast 1976;18:142-51.

[36] Herndon DN, Rose JK. Cadaver skin allograft and the transmission of human cytomegalovirus in burn patients: benefits clearly outweigh risks. J Am Coll Surg 1996;182:263-4.

[37] Bordes J, Maslin J, Prunet B, d'Aranda E, Lacroix G, Goutorbe P, et al. Cytomegalovirus infection in severe burn patients monitoring by real-time polymerase chain reaction: $\mathrm{A}$ prospective study. Burns J Int Soc Burn Inj 2011;37:434-9. doi:10.1016/j.burns.2010.11.006.

[38] Gong F, Ding L, Jiang D, Zhang C, Shen W, Pan Y. Association of human leukocyte antigen $E$ polymorphism with human cytomegalovirus reactivation in Chinese burn patients. Acta Biochim Biophys Sin 2013;45:982-4. doi:10.1093/abbs/gmt103.

[39] Seeman J, Königová R, Lysenková I. Fatal outcome of cytomegalovirus infections in severe burns. Acta Chir Plast 1980;22:166-70.

[40] Kagan RJ, Naraqi S, Matsuda T, Jonasson OM. Herpes simplex virus and cytomegalovirus infections in burned patients. J Trauma 1985;25:40-5.

[41] Bourdarias B, Perro G, Cutillas M, Castede JC, Lafon ME, Sanchez R. Herpes simplex virus infection in burned patients: epidemiology of 11 cases. Burns $\mathrm{J}$ Int Soc Burn Inj 1996;22:287-90.

[42] Manders SM, Chetty BV. Eczema herpeticum occurring in autografted skin. J Am Acad Dermatol 1991;24:509-10.

[43] Bartralot R, García-Patos V, Rodríguez-Cano L, Castells A. Kaposi's varicelliform eruption in a patient with healing second degree burns. Clin Exp Dermatol 1996;21:127-30.

[44] McGill SN, Cartotto RC. Herpes simplex virus infection in a paediatric burn patient: case report and review. Burns J Int Soc Burn Inj 2000;26:194-9.

[45] Meuli M, Lips U, Nadal D. A toddler with burns, stomatitis, and skin graft loss. Burns J Int Soc Burn Inj 2000;26:625-7.

[46] Sheridan RL, Schulz JT, Weber JM, Ryan CM, Pasternack MS, Tompkins RG. Cutaneous herpetic infections complicating burns. Burns J Int Soc Burn Inj 2000;26:621-4.

[47] Chen C-C, Chen C-L, Chiang C-H, Pan S-C. Herpes simplex infection in a minor burn wound: a case report. J Burn Care Rehabil 2005;26:453-5.

[48] Werdin F, Rennekampff H-O, Schaller H-E, Jahn G, Hamprecht K. Thymidine Kinase Sequence Analysis of Herpes Simplex Virus Type 1 Strains Present in Different Compartments in an Atypical Impetiginous Rash on the Lesional Skin of a Burn Patient. J Clin Microbiol 2008;46:3162-4. doi:10.1128/JCM.00552-08.

[49] Nishimura M, Maekawa M, Hino Y, Mihara K, Kohda H. Kaposi's varicelliform eruption. Development in a patient with a healing second-degree burn. Arch Dermatol 1984;120:799-800.

[50] Jones CA, Walker KS, Badawi N. Antiviral agents for treatment of herpes simplex virus infection in neonates. Cochrane Database Syst Rev 2009:CD004206. doi:10.1002/14651858.CD004206.pub2. 


\section{Figure legends}

Fig. 1. Flowchart describing the literature review process.

\section{Tables}

Table 1. Studies included in the systematic analysis.

Table 2. Concise summary of all included studies. 
Table 1. Studies included in the systematic analysis.

\begin{tabular}{|c|c|c|c|c|c|c|c|c|c|c|c|c|c|c|c|c|}
\hline $\begin{array}{l}\text { 훌 } \\
\text { क }\end{array}$ & 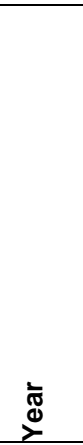 & 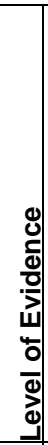 & 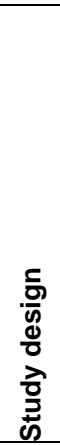 & 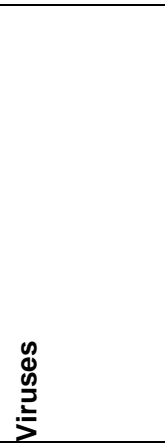 & $\begin{array}{l}\bar{\pi} \\
\stackrel{0}{0} \\
z\end{array}$ & 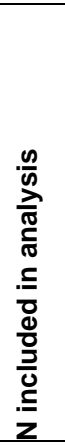 & 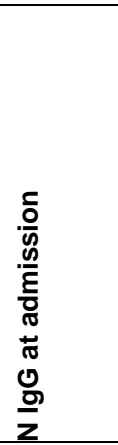 & 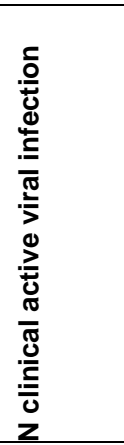 & 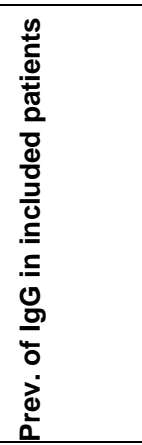 & 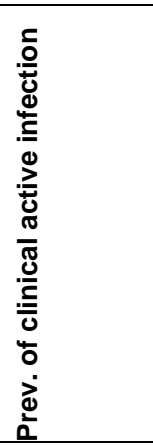 & $\begin{array}{l}\bar{\sigma} \\
\stackrel{0}{0} \\
8 \\
\frac{d}{0} \\
z\end{array}$ & 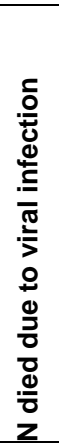 & $\begin{array}{l}\frac{}{0} \\
\frac{0}{0} \\
\frac{0}{0} \\
\stackrel{0}{0} \\
\stackrel{2}{>}\end{array}$ & 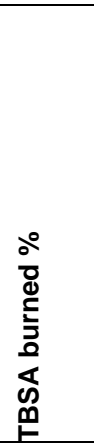 & $\stackrel{8}{8}$ & 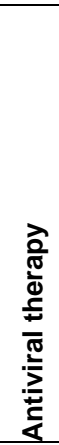 \\
\hline $\begin{array}{l}\text { Seeman and } \\
\text { Koenigova }\end{array}$ & 1976 & 3 & RA & CMV & 160 & 74 & 54 & 15 & $73 \%$ & $20 \%$ & 3 & ND & Serum, Urine & $>20 \%$ & ND & $\mathrm{ND}$ \\
\hline Matthews et al. & 1979 & 2 & $\mathrm{PA}$ & $\begin{array}{l}\text { CMV, HSV, } \\
\text { VZV, } \\
\text { Vaccinia }\end{array}$ & 30 & 30 & ND & 10 & ND & ND & ND & ND & $\begin{array}{l}\text { Serum, Urine, } \\
\text { respiratory tract } \\
\text { and laesions }\end{array}$ & $\begin{array}{l}3 \text { to } \\
80 \%\end{array}$ & $\begin{array}{l}0.3 \text { to } \\
87\end{array}$ & ND \\
\hline Seeman et al. & 1980 & 3 & RA & CMV & 150 & 150 & ND & ND & ND & $70 \%$ & 7 & 7 & Serum, Urine & $\begin{array}{l}20 \text { to } \\
80 \%\end{array}$ & $\begin{array}{l}9 \text { to } \\
63\end{array}$ & ND \\
\hline \multirow[t]{2}{*}{$\begin{array}{l}\text { Linnemann and } \\
\text { MacMillan }\end{array}$} & 1981 & 3 & RA & $\begin{array}{l}\text { Adenov., } \\
\text { CMV, EBV, } \\
\text { HSV, VZV, }\end{array}$ & 40 & 40 & ND & $\begin{array}{l}9 \text { CMV, } \\
3 \text { EBV \& } \\
\text { HSV, } \\
2 V Z V\end{array}$ & ND & $\begin{array}{l}22 \% \text { CMV } \\
8 \% \text { EBV \& } \\
\text { HSV, 5\% } \\
\text { VZV }\end{array}$ & ND & ND & Serum & $38 \%^{5}$ & 8 & ND \\
\hline & & 2 & $\mathrm{PA}$ & $\begin{array}{l}\text { Adenov., } \\
\text { CMV, HSV }\end{array}$ & 24 & 24 & $\begin{array}{l}2 \text { CMV, } \\
\text { other } \\
\text { ND }\end{array}$ & $\begin{array}{l}8 \mathrm{CMV}, \\
6 \mathrm{HSV} \\
4 \\
\text { Adenov. }\end{array}$ & $\begin{array}{l}\text { 8\% CMV, } \\
\text { other ND }\end{array}$ & $\begin{array}{l}25 \% \text { HSV, } \\
17 \% \\
\text { Adenov. }\end{array}$ & ND & ND & $\begin{array}{l}\text { Serum, urine, } \\
\text { respiratory tract }\end{array}$ & $28 \%^{b}$ & 9 & ND \\
\hline Kagan et al. & 1985 & 2 & PA & CMV, HSV & 52 & 52 & $\begin{array}{l}41 \text { CMV } \\
\text { \&/or } \\
\text { HSV }\end{array}$ & 27 & $79 \%$ & $52 \%$ & 16 & 10 & $\begin{array}{l}\text { Serum, sputum, } \\
\text { urine, wound }\end{array}$ & $36 \%$ & 29 & ND \\
\hline Munster et al. & 1987 & 1 & PA & CMV & 20 & 20 & $52 \%$ & 0 & $52 \%$ & $0 \%$ & 8 & 0 & Serum & $37 \%$ & 48 & $\lg G$ \\
\hline Kealey et al. & 1987 & 2 & PA & CMV & 59 & 59 & 22 & ND & $37 \%$ & ND & 2 & ND & Serum & $\begin{array}{l}3 \text { to } \\
75 \%\end{array}$ & $\begin{array}{l}1 \text { to } \\
76\end{array}$ & No \\
\hline Moran et al. & 1988 & 1 & $\mathrm{PA}$ & CMV & 120 & 20 & $62 \$$ & 16 & ND & $80 \%$ & 8 & ND & Serum & 29 & 37 & $\lg G$ \\
\hline Bale et al. & 1990 & 2 & $\mathrm{PA}$ & CMV & 120 & 120 & 53 & ND & $44 \%$ & ND & 1 & ND & Serum, urine & $\begin{array}{l}1 \text { to } \\
82 \%\end{array}$ & $\begin{array}{l}0.25 \\
\text { to } 73\end{array}$ & ND \\
\hline $\begin{array}{l}\text { Bourdarias et } \\
\text { al. }\end{array}$ & 1996 & 3 & RA & HSV-1 & 280 & 280 & ND & 11 & ND & $4 \%$ & 0 & ND & Serum, skin & $23 \%^{b}$ & 39 & No \\
\hline
\end{tabular}




\begin{tabular}{|c|c|c|c|c|c|c|c|c|c|c|c|c|c|c|c|c|}
\hline Byers et al. $^{a}$ & 1996 & 3 & $\mathrm{RA}$ & HSV & 54 & 54 & ND & 27 & ND & $50 \%$ & 54 & 11 & Lung tissue & 56 & $36 \%{ }^{\mathrm{C}}$ & ND \\
\hline Kealey et al. & 1996 & 2 & PA & CMV & 493 & 23 & ND & 3 & ND & $13 \%$ & 0 & 0 & Serum, Urine & $\begin{array}{l}18 \text { to } \\
63\end{array}$ & $\begin{array}{l}0.6 \\
\text { to50 }\end{array}$ & No \\
\hline Sheridan et al. & 1999 & 3 & RA & VZV & $\begin{array}{l}886 \\
9 \\
\end{array}$ & $\begin{array}{l}886 \\
9 \\
\end{array}$ & ND & 15 & ND & $0.2 \%$ & ND & 1 & Serum & ND & ND & Yes \\
\hline Fidler et al. & 2002 & 3 & RA & HSV-1 & 95 & 95 & ND & 19 & ND & $20 \%$ & 25 & 3 & Skin & $>20 \%$ & $\begin{array}{l}21 \text { to } \\
70\end{array}$ & Yes \\
\hline $\begin{array}{l}\text { D`Avignon et } \\
\text { al. }^{\text {a }}\end{array}$ & 2010 & 3 & RA & CMV & 228 & 97 & ND & $\begin{array}{l}4 \mathrm{HSV}, \\
1 \mathrm{CMV}\end{array}$ & ND & $5 \%$ & 228 & 5 & $\begin{array}{l}\text { Respiratory } \\
\text { tract }\end{array}$ & $\begin{array}{l}35- \\
60 \%\end{array}$ & $\begin{array}{l}27 \text { to } \\
88\end{array}$ & ND \\
\hline Bordes et al. & 2011 & 2 & PA & CMV & 140 & 29 & 21 & 16 & $72 \%$ & $55 \%$ & 5 & 3 & Serum & $>15 \%$ & $\begin{array}{l}29 \text { to } \\
83\end{array}$ & ND \\
\hline Sen et al. & 2012 & 3 & RA & $\begin{array}{l}\text { HSV-1, } \\
\text { HSV } 2\end{array}$ & 71 & 71 & ND & $\begin{array}{l}20 \text { HSV- } \\
1,1 \\
\text { HSV-2 }\end{array}$ & ND & $30 \%$ & $20 \%^{d}$ & $19 \%^{\mathrm{d}}$ & $\begin{array}{l}\text { Skin, urine, } \\
\text { respiratory tract }\end{array}$ & $\begin{array}{l}43 \\
\text { to } 49 \%\end{array}$ & $\begin{array}{l}38 \text { to } \\
47\end{array}$ & Yes \\
\hline Gong et al. & 2013 & 3 & $\mathrm{PA}$ & CMV & ND & 160 & 160 & 108 & ND & $68 \%$ & ND & ND & Serum & $34 \%$ & 34 & ND \\
\hline
\end{tabular}

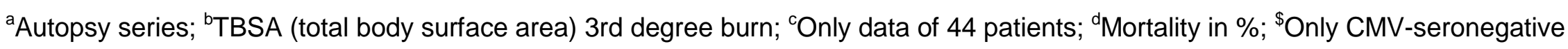
patients have been enrolled in further study; Adenov: Adenovirus; ND: not described; TBSA: total body surface area; CMV:

cytomegalovirus; EBV: Epstein-Barr virus; HSV: human herpes virus; VZV: varicella zoster virus; Prev: prevalence; RA: retrospective analysis; PA: prospective analysis 
Table 2. Concise summary of all included studies.

\begin{tabular}{|c|c|c|}
\hline Study & Year & Summary \\
\hline Seeman and Koenigova & 1976 & $\begin{array}{l}\text { In a retrospective analysis of } 160 \text { patients, } 74 \text { fulfilled inclusion criteria and } 54 \text { had serum positive CMV titer. Fifteen had clinically } \\
\text { relevant elevated serum levels and three patients died due to CMV. }\end{array}$ \\
\hline Matthews et al. & 1979 & $\begin{array}{l}\text { A prospective serum analysis of } 30 \text { cases regarding HSV, CMV and VZV was performed. } 10 \text { patients showed evidence of active viral } \\
\text { infections (( } 5 \mathrm{HSV}, 1 \mathrm{VZV}, 1 \mathrm{CMV}, 2 \text { with } \mathrm{CMV} \text { and HSV, } 1 \text { Vaccinia). }\end{array}$ \\
\hline Seeman et al. & 1980 & The retrospective analysis of 150 cases showed a prevalence of $70 \%$; in seven cases CMV was found as cause of death. \\
\hline \multirow[t]{2}{*}{ Linnemann and MacMillan } & \multirow[t]{2}{*}{1981} & $\begin{array}{l}\text { A retrospective serum analysis of } 40 \text { patients was performed; } 22 \% \text { had active levels for } \mathrm{CMV}, 5 \% \text { for } \mathrm{VZV}, 8 \% \text { for } \mathrm{HSV} \text { and } 8 \% \text { for } \\
\text { EBV. }\end{array}$ \\
\hline & & $\begin{array}{l}\text { A prospective study including } 24 \text { burned children showed } 33 \% \text { an infection of CMV, } 25 \% \mathrm{HSV} \text {, and } 17 \% \text { adenovirus. Four children had } \\
\text { more than one virus infection during the study. }\end{array}$ \\
\hline Kagan et al. & 1985 & $\begin{array}{l}52 \text { prospectively enrolled burn patients showed a prevalence for viral infections (CMV and/or HSV) of } 52 \% \text {. Important factors for the } \\
\text { incidence of these viruses were: age, facial burn, inhalation injury, full-thickness burn and length of hospitalization. }\end{array}$ \\
\hline Munster et al. & 1987 & $\begin{array}{l}\text { A prospective randomized double-blind trial of intravenous immunoglobulin administration in } 20 \text { burn patients was performed. CMV } \\
\text { antibody titer was significantly increased in IgG treated group, but decreased to normal } 7 \text { days post treatment. No impact of } \\
\text { prophylactic IgG therapy on CMV incidence was visible. }\end{array}$ \\
\hline Kealey et al. & 1987 & $\begin{array}{l}\text { The authors performed a prospective serological analysis of } 59 \text { burn victims. A CMV seroprevalence of } 37 \% \text { was observed, and six } \\
\text { patients seroconverted at the one month follow-up. There was no association between seroconversion and clinical complications. }\end{array}$ \\
\hline Moran et al. & 1988 & $\begin{array}{l}\text { In a prospective analysis, } 120 \text { patients were for CMV serum titer antibodies with a prevalence of } 52 \% \text {. A prospective randomized } \\
\text { double-blind trial was performed for immunoglobulin G therapy as CMV infection prevention. There were no differences between } \\
\text { treated and untreated groups regarding morbidity and mortality. }\end{array}$ \\
\hline Bale et al. & 1990 & $\begin{array}{l}\text { A prospective serum analysis was performed of } 120 \text { burn patients, } 44 \% \text { were seropositive for CMV at admission. Of the seronegative } \\
\text { patients, } 8 \text { seroconverted during the follow-up. No clinically relevant CMV case was described. }\end{array}$ \\
\hline
\end{tabular}




\begin{tabular}{|c|c|c|}
\hline Bourdarias et al. & 1996 & $\begin{array}{l}280 \text { patients were retrospectively analyzed, } 11 \text { developed a HSV-1 infection during hospitalization. No antiviral treatment was } \\
\text { administered and wound healing was delayed in these cases. Fever was observed in the majority of acute HSV-1 infections. }\end{array}$ \\
\hline Byers et al. $^{a}$ & 1996 & $\begin{array}{l}\text { A retrospective autopsy series showed an incidence of HSV in } 50 \% \text { of lung samples from } 54 \text { patients. The authors suggest that earlier } \\
\text { detection and treatment of pulmonary herpes infection may reduce morbidity and mortality of burn victims. }\end{array}$ \\
\hline Kealey et al. & 1996 & $\begin{array}{l}\text { The authors prospectively enrolled } 493 \text { patients, } 22 \text { patients were seronegative at admission and required cadaver allografts. Five of } \\
\text { them seroconverted during the hospitalization. Four of them developed a clinically relevant CMV infection. }\end{array}$ \\
\hline Sheridan et al. & 1999 & $\begin{array}{l}\text { In this study, an incidence of VZV in pediatric burns of } 0.1 \% \text { was seen over a } 15 \text { year period. One of } 15 \text { patients died as a result of } \\
\text { VZV induced pneumonitis. Final conclusions were that prophylactic acyclovir and VZV immunoglobulin therapy in infected severely } \\
\text { burned children should be considered. }\end{array}$ \\
\hline Fidler et al. & 2002 & $\begin{array}{l}\text { In a retrospective chart review of } 95 \text { cases, } 19 \text { had facial rashes indicating a HSV infection while } 15 \text { had positive cultures. Thirteen } \\
\text { underwent aciclovir treatment. There were no difference between treated and untreated groups regarding morbidity and mortality. }\end{array}$ \\
\hline D`Avignon et al. ${ }^{a}$ & 2010 & $\begin{array}{l}\text { Autopsy report of } 97 \text { autopsies, review of bacterial and viral infections and their role in mortality. Twenty seven patients died due to a } \\
\text { bacterial infection, } 5 \text { due to viral infection. }\end{array}$ \\
\hline Bordes et al. & 2011 & $\begin{array}{l}\text { Prospective analysis of } 29 \text { burn patients for CMV infection using RT-PCR on blood samples. } 21 \text { were positive for anit-CMV lgG, } 15 \text { had } \\
\text { an active CMV infection. No significant difference in mortality between active and inactive infections. }\end{array}$ \\
\hline Sen et al. & 2012 & $\begin{array}{l}\text { Retrospective review of HSV activation including } 71 \text { severely burned adult patients. Twenty patients with HSV activation received } \\
\text { acyclovir. No difference in mortality between infected and uninfected was seen. }\end{array}$ \\
\hline Gong et al. & 2013 & $\begin{array}{l}\text { The authors prospectively included } 160 \text { burned patients to determine the human leukocyte antigen } E(H L A-E) \text { polymorphisms in } \\
\text { reactivation of } C M V \text { in burns. One hundred eight patients reactivated during their hospitalization, most of whom were homozygous for } \\
\text { the } H L A-W^{*} 0101 \text { allele. }\end{array}$ \\
\hline
\end{tabular}

${ }^{a}$ Autopsy series; Adenov: Adenovirus; TBSA: total body surface area; CMV: cytomegalovirus; EBV: Epstein-Barr virus; HSV: human herpes virus; VZV: varicella zoster virus. 